\title{
TRPC4 wt Allele
}

National Cancer Institute

\section{Source}

National Cancer Institute. TRPC4 wt Allele. NCI Thesaurus. Code C102487.

Human TRPC4 wild-type allele is located in the vicinity of 13q13.3 and is approximately $234 \mathrm{~kb}$ in length. This allele, which encodes short transient receptor potential channel 4 protein, is involved in the modulation of cellular calcium. 